\title{
Balance Sheet Method Assessment for Nitrogen Fertilization in Bread Wheat: I. Yield and Quality
}

\author{
Maria Corbellini ${ }^{1}$, Maurizio Perenzin ${ }^{1}$, Gaetano Boggini $^{1}$, Gianni Bellocchi ${ }^{*}$, \\ Diego Scudellari ${ }^{3}$, Mario Monotti ${ }^{4}$ \\ ${ }^{1}$ Consiglio per la Ricerca e la Sperimentazione in Agricoltura, Istituto Sperimentale per la Cerealicoltura, \\ Sant'Angelo Lodigiano (Lodi), Italy \\ ${ }^{2}$ Consiglio per la Ricerca e la Sperimentazione in Agricoltura, Istituto Sperimentale per le Colture \\ Industriali, Bologna, Italy \\ ${ }^{3}$ Centro Ricerche Produzioni Vegetali, Imola (Bologna), Italy \\ ${ }^{4}$ Dipartimento di Scienze Agroambientali e della Produzione Vegetale, sezione di Agronomia \\ e Coltivazioni Erbacee, Università di Perugia, Italy
}

Received: 26 October 2004. Accepted: 17 March 2006

\begin{abstract}
In the European Union the production of high quality wheat is mainly located in the Mediterranean regions where the climatic conditions positively affect protein concentration in the grain. High quality wheat calls for proper management of nitrogen fertilization, thus there is a need to verify whether the limitations imposed by local governments on maximum rate of nitrogen fertilization admitted may affect bread making quality. Trials were conducted in fourteen environments (E) to study the effects of different nitrogen fertilizations on eight cultivars (C), belonging to four quality grades (Q). Nitrogen (N) was applied to crops according to three rates/modalities: N1 corresponding to the maximum rate admitted calculated according to a balance sheet method and distributed at the stage of spike initiation; $\mathrm{N} 2$ with $50 \mathrm{~kg} \mathrm{ha}^{-1}$ of nitrogen more than $\mathrm{N} 1$, also distributed at the stage of spike initiation; N3 with $50 \mathrm{~kg} \mathrm{ha}^{-1}$ of nitrogen more than N1 but distributed at the stage of flag leaf appearance. The effects of environment, nitrogen and cultivar were significant for grain yield, test weight, 1000 kernel weight, heading time, plant height and for quality traits (protein content and alveograph indices). The existence of variability among cultivars and quality grades in the response to rate and timing of nitrogen fertilization was demonstrated by the significance of NxC and NxQ interactions. Dry matter and nitrogen contents of plant at anthesis and at harvest were significantly affected by the main sources of variation. High quality cultivars yielded more grain of better quality with higher $\mathrm{N}$ rates (N2 and $\mathrm{N} 3$ ) as compared to the maximum rate of nitrogen admitted by the local government (N1). These results demonstrated that the adopted balance sheet method for the calculation of $\mathrm{N}$ requirements of wheat crop adversely affects the full potential expression of the cultivars belonging to superior bread making quality grades.
\end{abstract}

Key-words: Triticum aestivum, nitrogen, fertilization, quality.

\section{Introduction}

In Italy bread wheat is cultivated in about 600000 hectares (ISMEA, 2002) and in the last decade farmers efforts have been directed to the production of bread wheat according to integrated crop management, which basically refers to the reduction of nitrogen $(\mathrm{N})$ inputs because usually there is no need of the chemical control of pests. However, higher levels of $\mathrm{N}$ fertilizer are required to achieve optimal protein content rather than to maximise grain yield, therefore the reduction of $\mathrm{N}$ supply may negatively affect the bread making quality of wheat (Holford et al., 1992; Miceli et al., 1992; Borghi et al., 1995; Triboi and Triboi-Blondel, 2001; Woolfolk et al., 2002). The production of high quality wheat is lacking in the European Union, thus a key objective of the Italian farmers is the exploitation of the opportunity offered by the Mediterranean climate to obtain superior crops (Borghi

\footnotetext{
* Corresponding Author: Tel.: +39 0332 786798; Fax: +39 0332 785483. E-mail address: gianni.bellocchi@jrc.it.
} 
et al., 1991). As a consequence, the acreage cultivated with cultivars characterised by high quality is increasing in Italy since the eighties, in spite of the decreasing of the total wheat area. The release of high yielding cultivars and the strengthening of a wheat market based on quality grade support this trend (Borghi et al., 1997). Wheat quality classification, based on protein content, alveograph and farinograph indices, defines four grades related to different end-uses of flour: improver wheat (Frumento di Forza, FF), superior bread-making wheat (Frumento Panificabile Superiore, FPS), ordinary bread-making wheat (Frumento Panificabile, FP), wheat for biscuits (Frumento da Biscotti, FB) (Borghi et al., 1997). Up to date, cultivars belonging to the first two classes are spread on more than $30 \%$ of the total acreage in Italy (Boggini et al., 2000); moreover, the home grown wheat is mainly employed in human consumption, thus the quality standards are very high. Before the introduction of integrated crop management, such end-use requirements incited wheat growers to slightly exceed in $\mathrm{N}$ supply. To control the potentially deleterious effects of nitrogen on environment, some limitations have been introduced in Italy since 1992 after the European directive 91/676 (nitrate directive) was published. Currently, the maximum amount of $\mathrm{N}$ rate admitted is locally determined, in most cases according to balance sheet methods (Grignani, 1995; Meynard et al., 1997). For instance, in the Emilia Romagna region, the main area for wheat cultivation in Italy (160000 ha), the adopted method considers the expected yield, the contribution of soil $\mathrm{N}$ content, the previous crop and the overwinter rainfall (Carnevali and Sarno, 1998). However the recommendations proposed are always based on the expected yield of medium quality cultivars and may result inadequate for those characterised by high bread making quality. As a consequence, there is concern about the need to define the most economically efficient and environmental sustainable wheat crop management for climatic conditions of the main bread wheat growing areas of Italy.

The main object of the first part of this study was to understand how the actual integrated crop management may affect the bread-making quality of wheat cultivars belonging to different market classes.

\section{Materials and methods}

Starting from 1997-1998, field experiments were conducted for three years at San Pancrazio (PR), Ravenna (RA) and Papiano di Marsciano (PG); for two years at Caleppio di Settala (MI); for one year at Ceregnano (RO), Lonigo (VI) and Mogliano Veneto (TV) (Table 1). Maximum rate of nitrogen admitted was calculated for all trials by means of a simplified balance sheet method according to the recommendations of the Emilia Romagna local government (Carnevali and Sarno, 1998). Briefly the method determined the amount of $\mathrm{N}$ supply balancing $\mathrm{N}$ uptake from the crop and $\mathrm{N}$ available for the crop from sources other than fertilization (see for details the web page www.caip.it/caip/CRPV/COLT.Concimazione.Azotata.htlm). N uptake was calculated applying a constant coefficients for yield unit $\left(0.0198 \mathrm{~kg} \mathrm{t}^{-1}\right.$ for grain, 0.006 $\mathrm{kg} \mathrm{t}^{-1}$ for straw, grain/straw ratio $\left.=1 / 0.8\right)$ on values derived from local historical average yields. $\mathrm{N}$ available for the crop was calculated summing up $\mathrm{N}$ in the soil at sowing, $\mathrm{N}$ mineralized from soil organic matter, $\mathrm{N}$ made available from residues of the preceding crop and $\mathrm{N}$ from organic fertilizers. A fraction of $\mathrm{N}$ available in the soil at sowing was assumed to be lost by leaching, depending on the rainfall amount in the period October-January. $\mathrm{N}$ made available from residues of the preceding crop depended on both crop species and soil conditions. According to the adopted method, $\mathrm{N}$ was applied in two splits, spaced of about 2 weeks, when the calculated $\mathrm{N}$ rate was above $100 \mathrm{~kg} \mathrm{ha}^{-1}$.

Soil analysis at sowing was performed according to SISS (1985), the soil textures ranged from clay to loam. Rainfall distribution pattern in the period from October to January was in the range from $153 \mathrm{~mm}$ (PR99) to $489 \mathrm{~mm}$ (PG98). The expected yield, determined according to the official national trials results (Perenzin et al.1997), was in the range 5.5-7.0 $\mathrm{t}$ $\mathrm{ha}^{-1}$. Three rate/modality of $\mathrm{N}$ fertilizations were applied: N1, corresponding to the maximum rate admitted (Table 1), distributed at Growth Stage (GS) 30 corresponding to the stage of spike initiation (Zadoks et al., 1974); N2 with $50 \mathrm{~N} \mathrm{~kg}$ ha $^{-1}$ more than N1, also distributed at GS 30; N3 with $50 \mathrm{~N} \mathrm{~kg} \mathrm{ha}^{-1}$ more than $\mathrm{N} 1$, the supplement being distributed at GS 40 (flag leaf appearance). When $\mathrm{N} 1$ was higher than $100 \mathrm{~kg} \mathrm{ha}^{-1}$, the 
rate was split in two timings: $2 / 3$ at GS 30 and $1 / 3$ at GS 32 (stem elongation). Nitrogen was given as granular ammonium nitrate at GS 30 and as urea at GS 32 and 40.

Two representative cultivars were chosen for each quality grade of the Italian classification for wheat quality: FF, Colfiorito and Golia; FPS, Bolero and Pandas; FP, Centauro and Mieti; FB, Eureka and Pascal.

The experimental design in each site was a split-plot with three replications. Nitrogen treatments (rate/modality) were assigned to the main plots and cultivars to the elementary plots of 10 $\mathrm{m}^{2}$ (eight rows, $17 \mathrm{~cm}$ apart, $7.5 \mathrm{~m}$ long). The experimental unit was represented by two adjacent plots, one for destructive sampling during growth and the other for combine harvesting.

Wheat was cultivated according to standard agronomic practices: sowing at dates in the months October-December with 450 viable seeds $\mathrm{m}^{-2}$, chemical control of weeds and no chemical control of leaf diseases. Heading time, plant height and, after seed cleaning, grain yield (13\% moisture), test weight, 1000 kernel weight were determined on each replication. Seed samples derived from the bulk of the three replications of each treatment were tempered overnight according to their hardness and milled with a BONA 4RB (Bona, Monza, Italy) experimental mill. The rate of flour extraction was in the range $60-65 \%$. Bread making quality was evaluated by means of Falling Number (method 3093; ISO, 1982), protein content (method 39-11; AACC, 1995) and Chopin alveograph indices (method 121; ICC, 1986).

In order to investigate the effects of $\mathrm{N}$ treatments on grain yield and quality, both accumulation and remobilisation of dry matter and nitrogen in the plant, roots excluded, have been studied during the grain filling period. In all sites, with the exclusion of MI99, plant samples of two replications of one cultivar for each quality class (FF: Colfiorito, FPS: Bolero, FP: Centauro, FB: Pascal) were collected at heading and harvest from $0.5 \mathrm{~m}$ of three randomly chosen rows excluding the bordering ones. After drying at $60{ }^{\circ} \mathrm{C}$ to constant weight, dry matter and nitrogen content (method 20483; ISO, 1982) of plant and grain were determined.

Standard statistical analysis of variance (ANOVA) was carried out by means of the MSTAT-C (1991) program considering the main sources of variation, Environment (E), Nitrogen (N) and Cultivar (C), as fixed factors. For factor $\mathrm{E}$ the 14 levels were represented by individual trials, while for factor $\mathrm{N}$ the three levels were represented by the combination of rate and modality of nitrogen supply. Differences among cultivars were further partitioned among the four quality grades $(\mathrm{Q})$. In the case of quality parameters determined on the bulk of the three replications, the second order interaction $(\mathrm{ExN})$ was used to test the significance of the main sources of variation $\mathrm{E}$ and $\mathrm{N}$, while the highest order interaction $(\mathrm{ExNxC})$ was used to test the significance of the main source of variation $\mathrm{C}$ ( $\mathrm{Q}$ components included) and of the lower order interactions.

\section{Results}

\subsection{Weather conditions}

Weather traits varied greatly among years and sites. Rainfall in the 1997-1998 season was below the average of the long term period in all locations but PG98. Rains from October to January (Table 1) accounted for $45-55 \%$ of the total; moreover February and March were very dry. In 1998-1999 total rainfall was near the long term average; rains during fall and winter accounted for $56-60 \%$ of the total at MI98, RA99 and PG99; at PR99 it was lower, accounting only for $42 \%$ of the total at the end of January. In 1999-2000 total rainfall was above average in all locations and concentrated for $65-70 \%$ in the October-January period.

\subsection{Grain yield and related traits}

Environment (E) and cultivar (C) significantly affected all the traits, while nitrogen $(\mathrm{N})$ significantly influenced grain yield, test weight and 1000 kernel weight (Table 2). The interactions between nitrogen and cultivar were significant for grain yield and test weight; interactions involving environment and nitrogen $(\mathrm{ExN})$ were significant for test weight and heading time. Environment $\mathrm{x}$ cultivar interactions $(\mathrm{ExC})$ were always significant.

Grain yield differed greatly among locations and years; generally the mean value of each environment agreed with those recorded in the official national trials (Perenzin et al., 1998, Perenzin et al., 1999; Perenzin et al., 2000). Grain pro- 
Table 1. Description of the environments: location, year, soil analysis, previous crop, rainfall and maximum rate of nitrogen admitted (N1).

\begin{tabular}{|c|c|c|c|c|c|c|c|c|c|c|}
\hline \multirow[b]{2}{*}{ Location } & \multirow[b]{2}{*}{ Year } & \multirow[b]{2}{*}{ Code } & \multicolumn{5}{|c|}{ Soil composition $(0-0.20 \mathrm{~m})^{\text {(a) }}$} & \multirow[b]{2}{*}{$\begin{array}{c}\text { Previous } \\
\text { crop }\end{array}$} & \multirow[b]{2}{*}{$\begin{array}{l}\text { Rainfall (b) } \\
\quad(\mathrm{mm})\end{array}$} & \multirow[b]{2}{*}{$\begin{array}{c}\mathrm{N} 1{ }^{(\mathrm{c})} \\
\left(\mathrm{kg} \mathrm{ha}^{-1}\right)\end{array}$} \\
\hline & & & $\begin{array}{l}\text { O.M. } \\
(\%)\end{array}$ & $\begin{array}{l}\mathrm{N} \text { tot } \\
\left(\mathrm{g} \mathrm{kg}^{-1}\right)\end{array}$ & $\begin{array}{l}\text { Sand } \\
(\%)\end{array}$ & $\begin{array}{l}\text { Clay } \\
(\%)\end{array}$ & $\begin{array}{l}\text { Silt } \\
(\%)\end{array}$ & & & \\
\hline \multirow[t]{2}{*}{ Caleppio di S. (MI) } & $1997-1998$ & MI98 & 2.1 & 1.4 & 40 & 21 & 39 & maize & 235 & 160 \\
\hline & 1998-1999 & MI99 & 1.6 & 1.4 & 40 & 21 & 38 & maize & 350 & 150 \\
\hline Ceregnano (RO) & 1997-1998 & RO98 & 2.2 & 1.6 & 12 & 31 & 57 & soybean & 259 & 100 \\
\hline Lonigo (VI) & $1997-1998$ & VI98 & 1.6 & 1.0 & 17 & 22 & 61 & soybean & 251 & 130 \\
\hline Mogliano V. (TV) & 1997-1998 & TV98 & 1.4 & 1.0 & 24 & 23 & 53 & soybean & 207 & 90 \\
\hline \multirow{3}{*}{ San Pancrazio (PR) } & $1997-1998$ & PR98 & 1.8 & 1.5 & 21 & 39 & 40 & sugar beet & 222 & 80 \\
\hline & 1998-1999 & PR99 & 1.8 & 1.6 & 21 & 39 & 40 & sugar beet & 153 & 63 \\
\hline & $1999-2000$ & PR00 & 1.5 & 1.6 & 21 & 39 & 40 & sugar beet & 333 & 76 \\
\hline \multirow[t]{3}{*}{ Ravenna (RA) } & 1997-1998 & RA98 & 1.6 & 1.1 & 10 & 26 & 64 & soybean & 318 & 120 \\
\hline & 1998-1999 & RA99 & 1.6 & 1.1 & 10 & 26 & 64 & sugar beet & 207 & 78 \\
\hline & $1999-2000$ & RA00 & 1.5 & 1.3 & 8 & 24 & 68 & tomato & 310 & 118 \\
\hline \multirow[t]{3}{*}{ Papiano di M. (PG) } & 1997-1998 & PG98 & 1.6 & 1.6 & 12 & 39 & 49 & sorghum & 489 & 150 \\
\hline & 1998-1999 & PG99 & 1.6 & 1.6 & 12 & 40 & 49 & sunflower & 328 & 129 \\
\hline & $1999-2000$ & PG00 & 1.6 & 1.4 & 11 & 44 & 45 & sunflower & 395 & 130 \\
\hline
\end{tabular}

(a) Soil analyses according to SISS (1985).

(b) From October $1^{\text {st }}$ to January $31^{\text {st }}$.

(c) $\mathrm{N} 1$ = Maximum rate of nitrogen fertilization admitted

ductions did not appear related to the maximum rate of nitrogen admitted in each site (N1). ANOVA carried out for the three locations common to the three year period showed that about $60 \%$ of the detected variation in grain yield was due to locations and only eight percent to years (data not reported).

The higher rate of nitrogen of the $\mathrm{N} 2$ and N3 treatments increased grain yield significantly of about $4 \%$ with respect to $\mathrm{N} 1$ in all environments, while differences between timing of fertilizer supply (N2 vs. N3) were not significant.

The highest grain yield was given by FB cultivars $\left(6.9 \mathrm{t} \mathrm{ha}^{-1}\right)$, the lowest by FPS cultivars $\left(6.2 \mathrm{t} \mathrm{ha}^{-1}\right)$. Such differences seem related to year of release of cultivars more than to quality grades: on average the more recently released cultivars Eureka (FB), Colfiorito (FPS) and Pascal (FB) were the highest yielding genotypes.

The significance of the ExC interaction was mainly due to Centauro (FP) and Golia (FF) that performed differently at TV98, MI98 and PG98 in comparison to the other sites. The significance of $\mathrm{NxC}$ indicated the existence of variability among cultivars in the response to rates and timing of nitrogen fertilization. Moreover, the $\mathrm{NxQ}$ interaction indicated a significant effect of both rates and timing of fertilization in the case of FF and FPS and of the nitrogen rates in the case of FP, while no effects resulted for the FB group (Figure 1).

Test weight varied significantly among environments: the minimum value was $70.3 \mathrm{~kg} \mathrm{hl}^{-1}$ at MI99 and the maximum was $82.5 \mathrm{~kg} \mathrm{hl}^{-1}$ at PR00. Differences due to nitrogen rate and timing, although statistically significant, had no practical meaning. Mean values for quality grades were highest in FPS and lowest in FB.

Kernel weight varied largely among environments (from $32.3 \mathrm{~g}$ at MI99 to $43.5 \mathrm{~g}$ at PR00). These differences and those due to nitrogen treatments and quality grades generally followed the same trend shown by test weight.

Heading and plant height greatly varied among environments, quality grades and varieties within grades, whilst nitrogen had no significant effects. Both characters showed a large range of variability in the environments: 11 days for heading and $23 \mathrm{~cm}$ for plant height.

\subsection{Grain quality}

Grain quality evaluation was carried out for all trials except PR99, owing to grain damage during storage. The main sources of variation $(\mathrm{E}$, $\mathrm{N}, \mathrm{C})$ significantly affected all the quality traits (Table 3). Variance due to environment was much higher than that due to nitrogen. As expected, quality grades gave higher variance than cultivars within grades. For all traits the differ- 
Table 2. Analysis of variance and mean values of agronomic parameters of eight cultivars belonging to four quality grades, grown in 14 environments (see Table 1 and text for abbreviations).

\begin{tabular}{|c|c|c|c|c|c|c|c|c|c|c|c|}
\hline Source of variation & \multirow[t]{2}{*}{ d.f. } & \multicolumn{2}{|c|}{$\begin{array}{l}\text { Grain yield } \\
\quad\left(\mathrm{t} \mathrm{ha}^{-1}\right)\end{array}$} & \multicolumn{2}{|c|}{$\begin{array}{l}\text { Test weight } \\
\left(\mathrm{kg} \mathrm{hl}^{-1}\right)\end{array}$} & \multicolumn{2}{|c|}{$\begin{array}{c}1000 \text { kernel } \\
\text { weight } \\
\text { (g) }\end{array}$} & \multicolumn{2}{|c|}{$\begin{array}{l}\text { Heading (a) } \\
\text { (days from } \\
\text { April } 1^{\text {st }} \text { ) }\end{array}$} & \multicolumn{2}{|c|}{$\begin{array}{l}\text { Plant } \\
\text { height (b) } \\
(\mathrm{cm})\end{array}$} \\
\hline A) Analysis of variance & & & & & & & & & & & \\
\hline Environment (E) & 13 & 162.6 & $* *$ & 739.3 & $* *$ & 587.0 & $* *$ & 764.4 & $* *$ & 4132.7 & $* *$ \\
\hline Replications within E & 28 & 0.7 & & 4.5 & & 15.1 & & 3.2 & & 34.6 & \\
\hline Nitrogen $(\mathrm{N})$ & 2 & 7.2 & $* *$ & 11.9 & $* *$ & 25.6 & $*$ & 2.1 & & 6.0 & \\
\hline $\mathrm{E} \times \mathrm{N}$ & 26 & 0.9 & & 5.2 & $* *$ & 9.4 & & 3.1 & $*$ & 20.9 & \\
\hline Error a & 56 & 0.6 & & 1.6 & & 6.6 & & 1.5 & & 21.5 & \\
\hline Cultivar (C) & 7 & 13.6 & $* *$ & 354.1 & $* *$ & 1629.4 & $* *$ & 446.5 & $* *$ & 6950.1 & $* *$ \\
\hline Quality grade (Q) & 3 & 21.4 & $* *$ & 233.8 & $* *$ & 1598.5 & $* *$ & 435.0 & $* *$ & 10185.8 & $* *$ \\
\hline $\mathrm{C}$ within $\mathrm{Q}$ & 4 & 7.7 & $* *$ & 444.3 & $* *$ & 1652.5 & $* *$ & 455.1 & $* *$ & 4523.3 & $* *$ \\
\hline $\mathrm{E} \times \mathrm{C}$ & 91 & 2.3 & $* *$ & 11.8 & $* *$ & 43.9 & $* *$ & 11.1 & $* *$ & 90.1 & $* *$ \\
\hline $\mathrm{N} \times \mathrm{C}$ & 14 & 0.6 & $* *$ & 3.1 & $*$ & 4.2 & & 1.5 & & 3.2 & \\
\hline $\mathrm{N} \times \mathrm{Q}$ & 6 & 0.7 & $* *$ & 3.0 & & 1.4 & & 1.6 & & 1.5 & \\
\hline $\mathrm{N} \times \mathrm{C}$ within $\mathrm{Q}$ & 8 & 0.5 & $*$ & 3.2 & & 6.3 & & 1.4 & & 4.4 & \\
\hline $\mathrm{E} \times \mathrm{N} \times \mathrm{C}$ & 182 & 0.3 & & 2.7 & $* *$ & 4.7 & $* *$ & 1.8 & & 9.5 & \\
\hline Error b & 588 & 0.2 & & 1.8 & & 3.2 & & 1.9 & & 8.8 & \\
\hline CV (\%) & & 7.5 & & 1.7 & & 4.6 & & 3.6 & & 3.5 & \\
\hline B) Mean values & & & & & & & & & & & \\
\hline Environment & & 6.8 & & 78.2 & & 39.3 & & 40.0 & & 94.0 & \\
\hline TV98 & & 8.3 & & 75.8 & & 38.6 & & 39.0 & & 86.0 & \\
\hline RO98 & & 7.3 & & 77.1 & & 38.0 & & 37.0 & & 94.0 & \\
\hline VI98 & & 8.3 & & 76.5 & & 41.2 & & 39.0 & & 79.0 & \\
\hline PR98 & & 5.8 & & 80.7 & & 38.4 & & - & & - & \\
\hline RA98 & & 8.5 & & 74.5 & & 39.2 & & 36.0 & & 93.0 & \\
\hline PG98 & & 6.1 & & 78.3 & & 36.3 & & 43.0 & & 75.0 & \\
\hline MI99 & & 3.1 & & 70.3 & & 32.3 & & 40.0 & & 87.0 & \\
\hline PR99 & & 5.2 & & 77.0 & & 35.5 & & - & & 83.0 & \\
\hline RA99 & & 7.0 & & 73.8 & & 39.4 & & 34.0 & & 84.0 & \\
\hline PG99 & & 5.5 & & 77.9 & & 39.0 & & 40.0 & & - & \\
\hline PR00 & & 6.0 & & 82.5 & & 43.5 & & - & & 71.0 & \\
\hline RA00 & & 7.9 & & 81.7 & & 39.6 & & 32.0 & & 88.0 & \\
\hline PG00 & & 5.7 & & 78.1 & & 42.9 & & 39.0 & & 78.0 & \\
\hline $\operatorname{LSD}(P \leq 0.05)$ & & 0.3 & & 0.4 & & 0.9 & & 0.4 & & 1.6 & \\
\hline Nitrogen & & & & & & & & & & & \\
\hline N1 & & 6.4 & & 77.4 & & 38.9 & & 38.0 & & 84.0 & \\
\hline $\mathrm{N} 2$ & & 6.6 & & 77.1 & & 38.5 & & 38.0 & & 84.0 & \\
\hline $\mathrm{N} 3$ & & 6.6 & & 77.5 & & 39.0 & & 38.0 & & 84.0 & \\
\hline$L S D(P \leq 0.05)$ & & 0.1 & & 0.2 & & 0.4 & & NS & & NS & \\
\hline Quality grade & & & & & & & & & & & \\
\hline $\mathrm{FF}$ & & 6.7 & & 78.0 & & 37.8 & & 37.0 & & 79.0 & \\
\hline FPS & & 6.2 & & 78.1 & & 41.6 & & 38.0 & & 86.0 & \\
\hline $\mathrm{FP}$ & & 6.4 & & 77.1 & & 35.9 & & 38.0 & & 79.0 & \\
\hline FB & & 6.9 & & 76.1 & & 40.0 & & 40.0 & & 93.0 & \\
\hline$L S D(P \leq 0.05)$ & & 0.1 & & 0.4 & & 0.5 & & 0.5 & & 1.0 & \\
\hline
\end{tabular}

NS: not significant; $* P \leq 0.05 ; * * P \leq 0.01$.

(a) only 11 sites.

(b) only 12 sites.

ences among cultivars changed with environments, while $\mathrm{NxC}$ and $\mathrm{NxQ}$ interactions were significant only for $\mathrm{W}$ and $\mathrm{P} / \mathrm{L}$ indices.

Protein content ranged from $9.5 \%$ at $\mathrm{RO} 98$ to $16.4 \%$ at PG00. No significant correlation was observed with grain yield. Protein content increased with nitrogen rates (from N1 to
N2/N3), with delay of supply (from N2 to N3) and differed among quality grades (from $12.8 \%$ in FB to $13.9 \%$ in FPS). Correlations between grain protein content and the alveograph parameters were significant and positive $(r=0.19$; $\mathrm{P}$ $<0.01$ ) for $\mathrm{W}$, which represents the strength of dough, but negative $(\mathrm{r}=-0.41 ; P<0.01)$ for $\mathrm{P} / \mathrm{L}$, 
Table 3. Analysis of variance and mean values of qualitative parameters of eight cultivars belonging to four quality grades, grown in 13 environments (see Table 1 and text for abbreviations).

\begin{tabular}{|c|c|c|c|c|c|c|c|c|c|c|c|}
\hline \multirow[t]{2}{*}{ Source of variation } & \multirow[t]{2}{*}{ d.f. } & \multirow{2}{*}{\multicolumn{2}{|c|}{$\begin{array}{c}\text { Protein } \\
\text { concentration } \\
(\%)\end{array}$}} & \multicolumn{7}{|c|}{ Alveograph } & \\
\hline & & & & \multicolumn{2}{|l|}{$\begin{array}{c}\mathrm{W} \\
\left(\mathrm{J} 10^{-4}\right)\end{array}$} & \multicolumn{2}{|l|}{$\begin{array}{c}\mathrm{P} \\
(\mathrm{mm})\end{array}$} & \multicolumn{2}{|l|}{$\begin{array}{c}\mathrm{L} \\
(\mathrm{mm})\end{array}$} & \multicolumn{2}{|l|}{$\mathrm{P} / \mathrm{L}$} \\
\hline \multicolumn{12}{|l|}{ A) Analysis of variance } \\
\hline Environment (E) & 12 & 96.7 & $* *$ & 133086 & $* *$ & 6284 & $* *$ & 15254 & $* *$ & 4.69 & $* *$ \\
\hline Nitrogen $(\mathrm{N})$ & 2 & 34.3 & $* *$ & 18810 & $* *$ & 146 & $*$ & 4426 & $* *$ & 0.51 & $*$ \\
\hline Error a & 24 & 1.0 & & 823 & & 51 & & 393 & & 0.09 & \\
\hline Cultivar (C) & 7 & 14.6 & $* *$ & 118393 & $* *$ & 21360 & $* *$ & 15459 & $* *$ & 12.92 & $* *$ \\
\hline Quality grade (Q) & 3 & 16.2 & $* *$ & 227428 & $* *$ & 40715 & $* *$ & 27656 & $* *$ & 24.87 & $* *$ \\
\hline $\mathrm{C}$ within $\mathrm{Q}$ & 4 & 13.4 & $* *$ & 36616 & $* *$ & 6844 & $* *$ & 6312 & $* *$ & 3.97 & $* *$ \\
\hline $\mathrm{N} \times \mathrm{C}$ & 14 & 0.4 & & 829 & $* *$ & 27 & & 90 & & 0.08 & $* *$ \\
\hline $\mathrm{N}$ x Q & 6 & 0.2 & & 1035 & $* *$ & 12 & & 50 & & 0.17 & $* *$ \\
\hline $\mathrm{N} \times \mathrm{C}$ within $\mathrm{Q}$ & 8 & 0.5 & & 674 & & 38 & & 120 & & 0.02 & \\
\hline $\mathrm{E} \times \mathrm{C}$ & 84 & 1.1 & $* *$ & 3329 & $* *$ & 241 & $* *$ & 1083 & $* *$ & 0.73 & $* *$ \\
\hline Error b & 168 & 0.3 & & 371 & & 27 & & 162 & & 0.04 & \\
\hline CV (\%) & & 4.2 & & 11.3 & & 8.2 & & 14.1 & & 21.4 & \\
\hline \multicolumn{12}{|l|}{ B) Mean values } \\
\hline \multicolumn{12}{|l|}{ Environment } \\
\hline & MI98 & 12.6 & & 302 & & 102 & & 82 & & 1.25 & \\
\hline & TV98 & 10.7 & & 144 & & 80 & & 56 & & 2.08 & \\
\hline & RO98 & 9.5 & & 125 & & 65 & & 61 & & 1.46 & \\
\hline & VI98 & 14.1 & & 254 & & 72 & & 116 & & 0.72 & \\
\hline & PR98 & 12.5 & & 164 & & 64 & & 97 & & 0.82 & \\
\hline & RA98 & 13.6 & & 161 & & 61 & & 103 & & 0.70 & \\
\hline & PG98 & 12.6 & & 98 & & 47 & & 79 & & 0.66 & \\
\hline & MI99 & 16.3 & & 261 & & 61 & & 145 & & 0.48 & \\
\hline & RA99 & 12.9 & & 96 & & 48 & & 76 & & 0.77 & \\
\hline & PG99 & 12.8 & & 120 & & 58 & & 70 & & 0.98 & \\
\hline & PR00 & 14.3 & & 226 & & 69 & & 111 & & 0.71 & \\
\hline & RA00 & 15.5 & & 82 & & 46 & & 72 & & 0.69 & \\
\hline & PG00 & 16.4 & & 83 & & 42 & & 78 & & 0.58 & \\
\hline$L S D$ & $\leq 0.05)$ & 0.3 & & 17 & & 3 & & 8 & & 0.18 & \\
\hline \multicolumn{12}{|l|}{ Nitrogen } \\
\hline & $\mathrm{N} 1$ & 12.7 & & 149 & & 62 & & 83 & & 0.99 & \\
\hline & $\mathrm{N} 2$ & 13.6 & & 165 & & 63 & & 91 & & 0.90 & \\
\hline & N3 & 13.9 & & 175 & & 64 & & 96 & & 0.85 & \\
\hline$L S D$ & $\leq 0.05)$ & 0.2 & & 8 & & 1 & & 4 & & 0.09 & \\
\hline \multicolumn{12}{|l|}{ Quality grade } \\
\hline & FF & 13.4 & & 217 & & 93 & & 67 & & 1.72 & \\
\hline & FPS & 13.9 & & 185 & & 58 & & 112 & & 0.58 & \\
\hline & FP & 13.4 & & 160 & & 61 & & 85 & & 0.89 & \\
\hline & FB & 12.8 & & 90 & & 38 & & 95 & & 0.47 & \\
\hline$L S D$ & $\leq 0.05)$ & 0.2 & & 6 & & 2 & & 2 & & 0.06 & \\
\hline
\end{tabular}

NS: not significant; $* P \leq 0.05 ; * * P \leq 0.01$.

i.e. the ratio between the resistance and the extensibility of dough.

Alveograph $\mathrm{W}$ mean values ranged in the

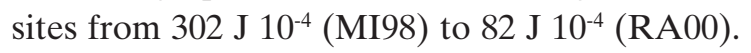
In four trials (MI98, VI98, MI99 and PR00) mean $\mathrm{W}$ values were higher than $220 \mathrm{~J} 10^{-4}$, value considered the bottom limit of the FPS grade (Borghi et al., 1997). In five sites (TV98, RO98, PR98, RA98, PG99) mean W values were in the range 120-164 $\mathrm{J}^{10-4}$ and in the other trials (PG98, RA99, RA00, PG00) they were very poor, lower than $100 \mathrm{~J} 10^{-4}$. On average, the strength of dough increased with nitrogen treat-

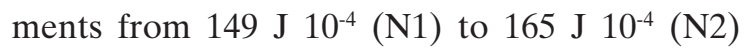
and up to $175 \mathrm{~J}^{-4}(\mathrm{~N} 3)$. The $\mathrm{W}$ values also varied among quality grades and between cultivars within grades. The range was from $90{\mathrm{~J} 10^{-4}}^{-}$ in FB to $217 \mathrm{~J} 10^{-4}$ in FF. Cultivars and grades 


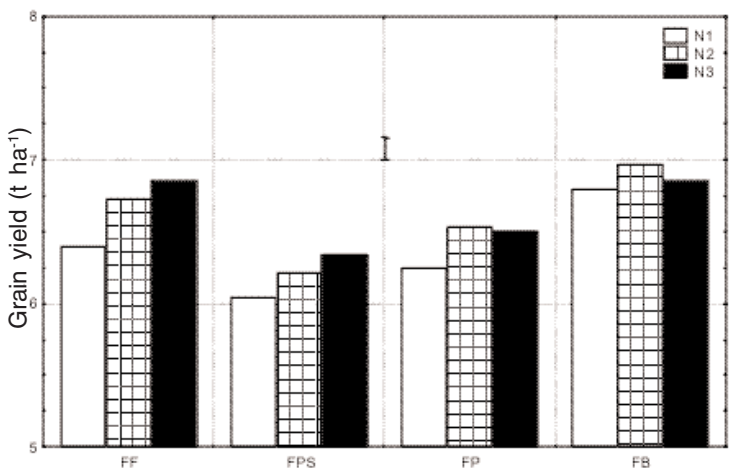

Figure 1. Interaction between nitrogen treatments (N1, N2, N3) and wheat quality grades (FF, FPS, FP, FB) for grain yield. Vertical bar represents LSD $(\mathrm{P} \leq 0.05)$.

behaved differently at variation of nitrogen supply: W increased in $\mathrm{N} 2$, as compared to $\mathrm{N} 1$, of $23 \mathrm{~J}^{1-4}$ in the case of FF, and of $7 \mathrm{~J}^{-4} 0^{-4}$ in the case of FB (Figure 2). Apart from FF, only little differences were observed between $\mathrm{N} 2$ and N3. Also ExC interaction was highly significant.

Alveograph $\mathrm{P} / \mathrm{L}$ ratios ranged among environments from 0.48 (MI99) to 2.08 (TV98). Mean values higher than 1.00 , associated with low grain protein content, were registered in the trials MI98 and RO98. The effects of nitrogen, although statistically significant, were in the range 0.85 (N3) - 0.99 (N1). Differences between quality grades were higher and in the range 0.47 (FB) - $1.72(\mathrm{FF})$. NxC and $\mathrm{NxQ}$ interactions were significant as a consequence of the different behaviour of $\mathrm{FF}$ as compared to the other quality grades (Figure 3). As for all other quality traits, ExC interaction was significant also for $\mathrm{P} / \mathrm{L}$ ratio.

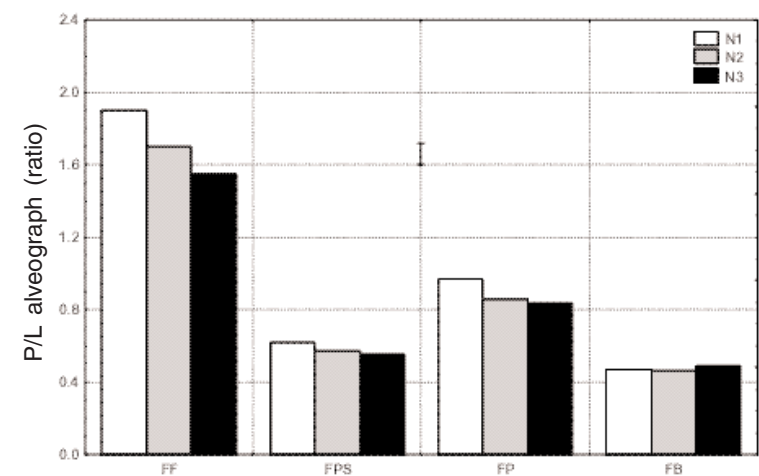

Figure 3. Interaction between nitrogen treatments (N1, N2, N3) and wheat quality grades (FF, FPS, FP, FB) for alveograph $\mathrm{P} / \mathrm{L}$ index. Vertical bar represents $\mathrm{LSD}(\mathrm{P} \leq 0.05)$.

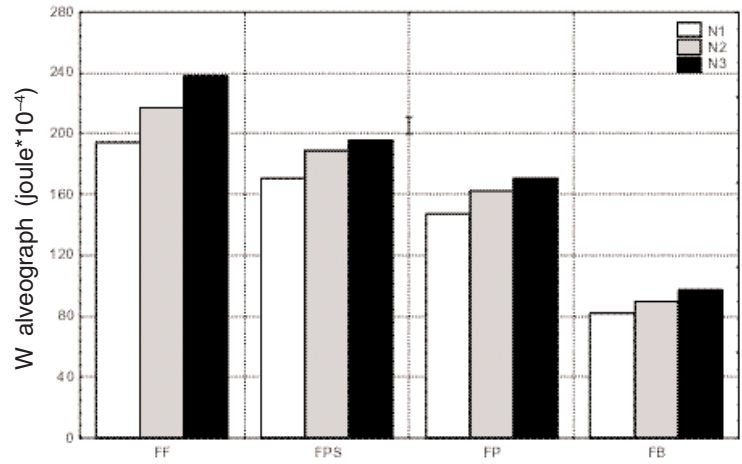

Figure 2. Interaction between nitrogen treatments (N1, N2, N3) and wheat quality grades (FF, FPS, FP, FB) for alveograph $\mathrm{W}$ index. Vertical bar represents LSD $(\mathrm{P} \leq 0.05)$.

\subsection{Dry matter and nitrogen content of the plant}

The dry weight of plant at anthesis and at harvest, dry matter of grain and straw at harvest as well as the harvest index values were significantly affected by environment and cultivar (Table 4). Differences due to nitrogen treatments were significant for plant weight and grain yield at harvest. The ExN interaction for plant dry matter at anthesis indicates differences of nitrogen effects in the sites. In fact, biomass weight increased from $\mathrm{N} 1$ to $\mathrm{N} 2$ and to $\mathrm{N} 3$ in some environments, while in others the opposite was true or no differences were found. Cultivars reacted differently in the environments for all characters shown in Table 4. The interaction $\mathrm{NxC}$ was significant only for plant and grain dry weight at harvest. Plant weight at anthesis did not change with nitrogen treatments, neither straw weight did; on the contrary, grain yield, and consequently plant weight, significantly increased from $\mathrm{N} 1$ to $\mathrm{N} 3$, suggesting that patterns of dry matter accumulation during grain filling were influenced by nitrogen fertilization.

Nitrogen contents of plant, grain and straw and nitrogen harvest index were significantly affected by the main sources of variation (E, N and $\mathrm{C}$ ) both at anthesis and at harvest (Table 5). Large differences resulted among mean values of all the above-mentioned traits in the sites and as a consequence of fertilization. In general N2 and N3 means were higher than N1 mean, and this behaviour was similar in all the environments. Interaction $\mathrm{NxC}$ was significant only for nitrogen content of plant and grain at harvest. The behaviour of cultivars was significantly different in the sites for all traits. Nitrogen 
Table 4. Analysis of variance and mean values of dry matter in the plant at two growth stages and in the grain and straw at harvest (see Table 1 and text for abbreviations).

\begin{tabular}{|c|c|c|c|c|c|c|c|c|c|c|}
\hline \multirow[t]{2}{*}{ Source of variation } & \multirow[t]{2}{*}{ d.f. } & \multirow{2}{*}{\multicolumn{2}{|c|}{$\begin{array}{c}\text { Anthesis } \\
\text { Plant } \\
\left(\mathrm{g} \mathrm{m}^{-2}\right)\end{array}$}} & \multicolumn{5}{|c|}{ Harvest } & \multirow{2}{*}{\multicolumn{2}{|c|}{$\begin{array}{l}\text { HI } \\
(\%)\end{array}$}} \\
\hline & & & & $\begin{array}{c}\text { Plant } \\
\left(\mathrm{g} \mathrm{m}^{-2}\right)\end{array}$ & $\begin{array}{c}\text { Grain } \\
\left(\mathrm{g} \mathrm{m}^{-2}\right)\end{array}$ & & $\begin{array}{l}\text { Straw } \\
\left(\mathrm{g} \mathrm{m}^{-2}\right)\end{array}$ & & & \\
\hline \multicolumn{11}{|l|}{ A) Analysis of variance } \\
\hline Environment (E) & 12 & 7774 & $* *$ & $8490 * *$ & 2463 & $* *$ & 3400 & $* *$ & 351 & $* *$ \\
\hline Replications within E & 13 & 194 & & 102 & 20 & & 59 & & 5 & \\
\hline Nitrogen $(\mathrm{N})$ & 2 & 179 & & $885 *$ & 446 & $* *$ & 79 & & 26 & \\
\hline $\mathrm{E} \times \mathrm{N}$ & 24 & 442 & $* *$ & 306 & 72 & & 130 & & 8 & \\
\hline Error a & 26 & 163 & & 221 & 56 & & 113 & & 9 & \\
\hline Cultivar (C) & 3 & 4652 & $* *$ & $8001 * *$ & 784 & $* *$ & 4319 & $* *$ & 177 & $* *$ \\
\hline $\mathrm{N} \times \mathrm{C}$ & 6 & 36 & & $502 *$ & 140 & $* *$ & 164 & & 10 & \\
\hline $\mathrm{E} \times \mathrm{C}$ & 36 & 380 & $* *$ & $978 * *$ & 228 & $* *$ & 361 & $* *$ & 19 & $* *$ \\
\hline $\mathrm{E} \times \mathrm{N} \times \mathrm{C}$ & 72 & 155 & & 229 & 73 & $* *$ & 85 & & 7 & \\
\hline Error $\mathrm{b}$ & 117 & 114 & & 212 & 37 & & 108 & & 6 & \\
\hline CV (\%) & & 9.3 & & 9.7 & 8.8 & & 12.7 & & 5.1 & \\
\hline \multicolumn{11}{|l|}{ B) Mean values } \\
\hline \multicolumn{11}{|l|}{ Environment } \\
\hline & MI98 & 1285.8 & & 1528.7 & 694.1 & & 834.6 & & 45.4 & \\
\hline & TV98 & 1234.4 & & 1772.1 & 836.3 & & 935.7 & & 47.8 & \\
\hline & RO98 & 1183.2 & & 1648.6 & 733.9 & & 914.8 & & 44.5 & \\
\hline & VI98 & 1032.5 & & 1695.5 & 841.8 & & 853.7 & & 49.8 & \\
\hline & PR98 & 1063.8 & & 1481.7 & 677.8 & & 803.9 & & 45.9 & \\
\hline & RA98 & 1519.1 & & 1632.4 & 804.2 & & 828.2 & & 49.2 & \\
\hline & PG98 & 1053.5 & & 1369.4 & 580.6 & & 788.9 & & 42.5 & \\
\hline & PR99 & 1171.8 & & 1484.7 & 641.1 & & 843.6 & & 43.2 & \\
\hline & RA99 & 1284.2 & & 1419.6 & 746.8 & & 672.7 & & 52.7 & \\
\hline & PG99 & 1100.3 & & 1207.2 & 514.6 & & 692.6 & & 42.7 & \\
\hline & PR00 & 759.2 & & 1183.7 & 593.4 & & 590.4 & & 50.1 & \\
\hline & RA00 & 1232.9 & & 1743.6 & 691.7 & & 1051.9 & & 39.5 & \\
\hline & PG00 & 1028.6 & & 1440.2 & 613.3 & & 826.9 & & 42.8 & \\
\hline$L S D$ & $\leq 0.05)$ & 76.1 & & 88.4 & 44.4 & & 63.1 & & 1.8 & \\
\hline \multicolumn{11}{|l|}{ Nitrogen } \\
\hline & N1 & 1135.8 & & 1475.7 & 667.5 & & 808.2 & & 45.4 & \\
\hline & N2 & 1161.8 & & 1517.1 & 694.1 & & 823.0 & & 45.8 & \\
\hline & N3 & 1152.2 & & 1532.1 & 708.3 & & 823.7 & & 46.4 & \\
\hline$L S D$ & $\leq 0.05)$ & NS & & 42.5 & 21.3 & & NS & & NS & \\
\hline \multicolumn{11}{|l|}{ Cultivar } \\
\hline Colfi & ito $(\mathrm{FF})$ & 1257.6 & & 1582.1 & 724.6 & & 857.5 & & 45.9 & \\
\hline Bo & o (FPS) & 1085.5 & & 1444.4 & 656.8 & & 787.6 & & 45.5 & \\
\hline Cen & ro (FP) & 1103.7 & & 1400.4 & 670.3 & & 730.1 & & 47.9 & \\
\hline & al (FB) & 1153.1 & & 1606.3 & 708.3 & & 898.0 & & 44.2 & \\
\hline$L S D$ & $\leq 0.05)$ & 33.8 & & 46.2 & 19.2 & & 33.0 & & 0.8 & \\
\hline
\end{tabular}

NS, not significant; $* P \leq 0.05 ; * * P \leq 0.01$.

harvest index was strongly correlated $(\mathrm{r}=0.64$; $P<0.01)$ with harvest index, with nitrogen content of grain $(\mathrm{r}=0.33 ; P<0.01)$ and straw $(\mathrm{r}=$ $-0.82 ; P<0.01)$ and with the alveograph index $\mathrm{W}(\mathrm{r}=0.34 ; P<0.01)$.

\section{Discussion and Conclusion}

The maximum rate of nitrogen fertilization admitted in different environments ranged from
63 to $160 \mathrm{~kg} \mathrm{ha}^{-1}$ (Table 1 ). The lowest rate was given at PR99 where the overwinter rainfall was very poor $(153 \mathrm{~mm})$ and wheat followed sugar beet, a crop considered to leave high nitrogen residue in the soil by the adopted balance sheet method (Carnevali and Sarno, 1998). In contrast, the highest rate of nitrogen was given at MI98 where overwinter rain was $235 \mathrm{~mm}$ and wheat followed a maize crop on a sandy soil. These two sites represented the range of variability normally detected for soils, climate con- 
Table 5. Analysis of variance and mean values of nitrogen content of plant at two growth stages and of grain and straw at harvest (see Table 1 and text for abbreviations).

\begin{tabular}{|c|c|c|c|c|c|c|c|c|c|c|c|}
\hline \multirow[t]{2}{*}{ Source of variation } & \multirow[t]{2}{*}{ d.f. } & \multirow{2}{*}{\multicolumn{2}{|c|}{$\begin{array}{c}\text { Anthesis } \\
\text { Plant } \\
\left(\mathrm{g} \mathrm{m}^{-2}\right)\end{array}$}} & \multicolumn{6}{|c|}{ Harvest } & \multirow{2}{*}{\multicolumn{2}{|c|}{$\begin{array}{r}\text { NHI } \\
(\%)\end{array}$}} \\
\hline & & & & $\begin{array}{c}\text { Plant } \\
\left(\mathrm{g} \mathrm{m}^{-2}\right)\end{array}$ & & $\begin{array}{c}\text { Grain } \\
\left(\mathrm{g} \mathrm{m}^{-2}\right)\end{array}$ & & $\begin{array}{c}\text { Straw } \\
\left(\mathrm{g} \mathrm{m}^{-2}\right)\end{array}$ & & & \\
\hline \multicolumn{12}{|l|}{ A) Analysis of variance } \\
\hline Environment (E) & 12 & 395 & $* *$ & 317 & $* *$ & 147 & $* *$ & 128 & $* *$ & 1297 & $* *$ \\
\hline Replications within E & 13 & 8 & & 6 & & 1 & & 3 & & 20 & \\
\hline Nitrogen $(\mathrm{N})$ & 2 & 149 & $* *$ & 142 & $* *$ & 82 & $* *$ & 20 & $*$ & 161 & $*$ \\
\hline $\mathrm{E} \times \mathrm{N}$ & 24 & 19 & $*$ & 14 & & 5 & & 5 & & 31 & \\
\hline Error a & 26 & 9 & & 9 & & 3 & & 5 & & 37 & \\
\hline Cultivar (C) & 3 & 112 & $* *$ & 106 & $* *$ & 39 & $* *$ & 38 & $* *$ & 234 & $* *$ \\
\hline $\mathrm{N} \times \mathrm{C}$ & 6 & 7 & & 27 & $*$ & 10 & $* *$ & 5 & & 14 & \\
\hline $\mathrm{E} \times \mathrm{C}$ & 36 & 15 & $*$ & 20 & $* *$ & 12 & $* *$ & 7 & $*$ & 77 & $* *$ \\
\hline $\mathrm{E} \times \mathrm{N} \times \mathrm{C}$ & 72 & 8 & & 11 & & 5 & $*$ & 4 & & 26 & \\
\hline Error b & 117 & 8 & & 9 & & 3 & & 4 & & 22 & \\
\hline CV (\%) & & 15,0 & & 13.6 & & 11.3 & & 25.4 & & 7.2 & \\
\hline \multicolumn{12}{|l|}{ B) Mean values } \\
\hline \multicolumn{11}{|l|}{ Environment } & \\
\hline & MI98 & 20.8 & & 21.1 & & 14.4 & & 6.6 & & 69.0 & \\
\hline & TV98 & 12.2 & & 22.3 & & 14.4 & & 7.8 & & 65.6 & \\
\hline & RO98 & 13.3 & & 20.9 & & 12.8 & & 8.1 & & 61.5 & \\
\hline & VI98 & 21.6 & & 29.5 & & 18.8 & & 10.7 & & 63.9 & \\
\hline & PR98 & 15.3 & & 18.7 & & 14.3 & & 4.5 & & 76.3 & \\
\hline & RA98 & 24.1 & & 27.4 & & 19.1 & & 8.3 & & 69.9 & \\
\hline & PG98 & 19.8 & & 23.9 & & 12.0 & & 12.1 & & 50.3 & \\
\hline & PR99 & 21.4 & & 21.2 & & 12.9 & & 8.2 & & 61.3 & \\
\hline & RA99 & 22.9 & & 21.6 & & 15.7 & & 5.9 & & 72.7 & \\
\hline & PG99 & 18.3 & & 19.5 & & 10.9 & & 8.5 & & 56.4 & \\
\hline & PR00 & 15.3 & & 18.5 & & 13.6 & & 4.8 & & 73.9 & \\
\hline & RA00 & 24.2 & & 27.1 & & 16.3 & & 10.8 & & 60.4 & \\
\hline & PG00 & 21.8 & & 26.8 & & 16.6 & & 10.1 & & 63.1 & \\
\hline$L S D$ & $\leq 0.05)$ & 1.8 & & 1.8 & & 1.0 & & 1.4 & & 3.6 & \\
\hline \multicolumn{11}{|l|}{ Nitrogen } & \\
\hline & N1 & 17.9 & & 21.6 & & 13.8 & & 7.9 & & 64.4 & \\
\hline & N2 & 19.8 & & 23.8 & & 15.1 & & 8.7 & & 64.1 & \\
\hline & N3 & 20.2 & & 23.5 & & 15.4 & & 8.0 & & 66.4 & \\
\hline$L S D$ & $\leq 0.05)$ & 0.9 & & 0.9 & & 0.5 & & 0.7 & & 1.7 & \\
\hline \multicolumn{11}{|l|}{ Cultivar } & \\
\hline Colfi & $\mathrm{o} \quad(\mathrm{FF})$ & 20.2 & & 23.4 & & 15.5 & & 7.9 & & 66.4 & \\
\hline & (FPS) & 20.5 & & 23.9 & & 14.8 & & 9.1 & & 62.4 & \\
\hline Cen & ro $(\mathrm{FP})$ & 18.1 & & 21.3 & & 13.8 & & 7.5 & & 65.5 & \\
\hline & al (FB) & 18.5 & & 23.1 & & 15.0 & & 8.1 & & 65.5 & \\
\hline$L S D$ & $\leq 0.05$ & 0.9 & & 1.0 & & 0.5 & & 0.7 & & 1.5 & \\
\hline
\end{tabular}

NS: not significant; $* P \leq 0.05 ; * * P \leq 0.01$.

ditions and cropping systems in the main bread wheat growing areas of Italy (Borghi et al., 1997). The absence of any significant correlation between grain yield and the maximum amount of nitrogen fertilization admitted in each site (N1), suggests that factors other than nitrogen supply are responsible for the variation in grain yield. The adopted balance-sheet method appeared suitable to match the crop $\mathrm{N}$ requirements in different environments according to seasonal variability in the rainfall pattern and soil $\mathrm{N}$ dynamics during the vegetative period, although high temperatures and drought during the grain filling period may significantly reduce wheat yield in the Mediterranean environments (Borghi et al., 1992; Monotti et al., 1992; Garrido-Lestache et al., 2004).

However, the best performances obtained for yield and quality traits with N2 and N3 treatments may indicate that the balance sheet method for the estimates of nitrogen requirements of wheat crop (N1) could limit the ex- 
pression of the varieties yield potential (Borghi et al., 1995; Lloveras et al., 2001). This appeared even more evident for the cultivars belonging to the FF and FPS grades, that yielded more grain of better quality (Figures 1,2,3) when the rate of nitrogen increased.

According to previous studies carried out in different environments (Blankenau et al., 2002) our experiments indicated that the higher rates of nitrogen of the treatments $\mathrm{N} 2$ and N3 allowed the accumulation of higher quantity of dry matter in the grain during the grain filling period. As $70-90 \%$ of wheat grain yield is produced by post-anthesis photosynthesis (Austin et al., 1977) any nitrogen shortage during grain filling may reduce more dry matter than nitrogen accumulation in the grain. In the same period, the nitrogen accumulation in the grain was almost the same in the three considered treatments, but the differences for nitrogen content of the plant were already significant at anthesis. At this stage the lowest nitrogen content of the plant $\left(17.9 \mathrm{~g} \mathrm{~m}^{-2}\right)$ was detected for $\mathrm{N} 1$, while $\mathrm{N} 2$ and N3 had values significantly higher but not different from each other. This picture was almost unchanged at harvest.

It is well known that in Mediterranean environments it is difficult to establish definite agronomic practices mainly because of the unpredictable climatic variations (Acevedo et al., 1999). Nevertheless our results indicated that the maximum rate of nitrogen calculated by the adopted sheet method should be revised in order to allow the production of high quality wheat. The apparent recovery efficiency of the extra supply of nitrogen and its true role in affecting the environment by leaching will be described in the second paper of this research (see part II) regarding the dynamics of nitrogen in the soils.

\section{Acknowledgements}

This work has been supported by Ministero delle Politiche Agricole e Forestali, Regione Lombardia, Regione Veneto, Regione Umbria (special grant: Sperimentazione Interregionale sui Cereali) and Regione Emilia Romagna (special grant: Verifica di Strategie di Fertilizzazione Azotata su Frumento Tenero). The technical assistance of: M. Poli (Azienda Sperimentale Marani); L. Castello (Azienda Sperimentale Stuard); S. Nannetti, G. Carnevali, G. Sarno (Regione Emilia Romagna); T. Lombardi (Agricola 2000); R. Converso
(Veneto Agricoltura); S. Padovan (Istituto di Genetica e Sperimentazione Agraria, N. Strampelli), R. Alberati (Università Perugia) and S. Empilli (Istituto Sperimentale per la Cerealicoltura) is gratefully acknowledged.

\section{References}

AACC 1995. Approved methods of the American Association of Cereal Chemists. th $^{\text {th }}$ ed. Method 39-11. The Association, St. Paul, MN.

Acevedo E.H., Silva P.C., Silva H.R., Solar B.R. 1999. Wheat production in Mediterranean environments. In: Satorre E.H., Slafer G.A. (eds.): Wheat ecology and physiology of yield determination. The Haworth Press, New York, 295-331.

Austin R.B., Ford M.A., Edrich J.A., Blackwell R.D. 1977. The nitrogen economy of winter wheat. J. Agric. Sci. Camb., 88:159-167.

Blankenau K., Olfs H.W., Kuhlmann H. 2002. Strategies to improve the use efficiency of mineral fertilizer nitrogen applied to winter wheat. J. Agron. \& Crop Sci., 188:146-154.

Boggini G., Empilli S., Esposti R., Corticelli C., Marchesini M., Silvi Antonini B., Mazza L., Canestrale R., Converso R., Padovan S., Balduini C., Cardone A.M. 2000. Caratteristiche qualitative del frumento tenero. Inf. Agr. Suppl., LVI, 33:45-50.

Borghi B., Corbellini M., Minoia C., Palumbo M., Di Fonzo N., Perenzin M. 1997. Effects of Mediterranean climate on wheat bread-making quality. Eur. J. Agron., 6:145-154.

Borghi B., Corbellini M., Perenzin M., Pogna N.E. 1991. Breeding for high quality bread wheats in Southern Europe: Results and perspectives. Vortr. Pflanzenzuchtg, 200:278-283.

Borghi B., Giordani G., Corbellini M., Vaccino P., Guermandi M., Toderi G. 1995. Influence of crop rotation, manure and fertilizers on bread making quality of wheat (Triticum aestivum L.). Eur. J. Agron., 4:37-45.

Borghi B., Guiducci M., Corbellini M., Monotti M. 1992. Attempts at avoiding the yield constraints of bread wheat (T. aestivum) in Mediterranean environments. J. Agron. \& Crop Sci., 168:49-60.

Carnevali G., Sarno G. 1998. Frumento. Linee tecniche di produzione integrata. La fertilizzazione. Terra e Vita (Suppl.), 37:32-34.

Garrido-Lestache E., Lopez-Bellido R.J., Lopez-Bellido L. 2004. Effect of $\mathrm{N}$ rate, timing and splitting and $\mathrm{N}$ type on bread-making quality in hard red spring wheat under rainfed Mediterranean conditions. Field Crops Res., 85:213-236.

Grignani C. 1995. Razionalizzazione della concimazione azotata del frumento tenero (Triticum aestivum L.) attraverso il metodo del bilancio azotato. Riv. di Agron. (3 Suppl.), 29:415-426.

Holford I.C.R., Doyle A.D., Leckie C.C. 1992. Nitrogen response characteristics of wheat protein in relation 
to yield responses and their interactions with phosphorus. Aust. J. Agric. Res., 43:969-986.

ICC 1986. Standard Methods of the International Association for Cereal Chemistry. Method n. 115-D. The Association, Vienna.

ISMEA 2002. Filiera frumento. Istituto di Servizi per il Mercato Agricolo Alimentare, Roma.

ISO 1982. Catalogue International Association for Standardization. 2nd ed. International Standard 3093 and 20483, ISO, Geneva.

Lloveras J., Lopez A., Ferran J., Espachs S., Solsona J. 2001. Bread-making wheat and soil nitrate as affected by nitrogen fertilization in irrigated Mediterranean conditions. Agron. J., 93:1183-1190.

Meynard J.M., Justes E., Machet J.M., Recous S. 1997. Fertilization azotée de cultures annuelles de plein champ. In: Lemaire G., Nicolardot B. (eds.): Maîtrise de l'azote dans les agrosystèmes. INRA, Paris, 271-288.

Miceli F., Martin M., Zerbi G. 1992. Yield, quality and nitrogen efficiency in winter wheat fertilised with increasing $\mathrm{N}$ levels at different times. J. Agron. \& Crop Sci., 168:337-344.

Monotti M., Borghi B., Guiducci M., Corbellini M. 1992. Condizioni ambientali durante la granigione e produttività del frumento tenero. Agric. e Ric., 14:63-74.
MSTAT-C 1991. A software program for the design, management and analysis of agronomic research experiments. Michigan State University, East Landing.

Perenzin M., Minoia C., Borghi B. 1997. I risultati della $24^{\text {a }}$ sperimentazione nazionale. Scelta delle varietà. Inf. Agr. Suppl., LIII (34):8-16.

Perenzin M., Minoia C., Corbellini M. 1998. Scelta delle varietà di grano tenero. Inf. Agr. Suppl., LIV (34):7-15.

Perenzin M., Notario T., Bertoli F., Boggini G. 2000. Scelta delle varietà. Inf. Agr. Suppl., LVI (33):5-14.

Perenzin M., Notario T., Boggini G. 1999. Scelta delle varietà di frumento tenero. Inf. Agr. Suppl., LV (34):7-16.

SISS 1985. Metodi normalizzati di analisi del suolo. Edagricole, Bologna.

Triboi E., Triboi-Blondel A.M. 2001. Environmental effects on wheat grain growth and composition. Asp. Appl. Biol. 64:91-101.

Woolfolk C.W., Raun W.R., Johnson G.V., Thomason W.E., Mullen R.W., Wynn K.J., Freeman K.W. 2002. Influence of late season foliar nitrogen applications on yield and grain nitrogen in winter wheat. Agron. J., 94:429-434.

Zadoks J.C., Chang T.T., Konzak C.F. 1974. A decimal code for growth stages of cereals. Weed Res., 14:415-421. 